\title{
UPAYA DAN IMPLIKASI PENYEDIAAN RUANG TERBUKA HIJAU (RTH)
}

\author{
Dadang Mashur dan Zaili Rusli \\ FISIP Universitas Riau, Kampus Bina Widya Km. 12,5 Simpang Baru Panam, Pekanbaru 28293
}

\begin{abstract}
Efforts and Implications of Green Open Space (RTH). The current urban problem has become a complicated problem to overcome. Urban development leads to negative con- sequences on several aspects, including environmental aspects. In the early stages of urban development, most of the land is green open space. However, there is a need for space to accommodate the population and its activities, the green space is likely to undergo conversion of land use to a wake area. Most of its surface, especially in the city center, is covered by roads, buildings and others with very complex characters and different from the green open space characters. These are exacerbated by weak law enforcement and public awareness of urban spatial planning, causing frequent flooding in urban areas, high air pollution and increased social vulnerability (crime and social crisis), decreased public productivity due to stress due to limited public space which are available for social interaction, and cause congestion problems due to high side barriers in certain road segments.
\end{abstract}

\begin{abstract}
Abstrak: Upaya dan Implikasi Ruang Terbuka Hijau (RTH). Masalah perkotaan pada saat ini telah menjadi masalah yang cukup pelik untuk diatasi. Perkembangan perkotaan membawa pada konsekuensi negatif pada beberapa aspek, termasuk aspek lingkungan. Dalam tahap awal perkembangan kota, sebagian besar lahan merupakan ruang terbuka hijau. Namun, adanya kebutuhan ruang untuk menampung penduduk dan aktivitasnya, ruang hijau tersebut cenderung mengalami konversi guna lahan menjadi kawasan terbangun. Sebagian besar permukaannya, terutama di pusat kota, tertutup oleh jalan, bangunan dan lain-lain dengan karakter yang sangat kompleks dan berbeda dengan karakter ruang terbuka hijau. Hal-hal tersebut diperburuk oleh lemahnya penegakan hukum dan penyadaran masyarakat terhadap aspek penataan ruang kota sehingga menyebabkan sering munculnya terjadi banjir di perkotaan, tingginya polusi udara, dan meningkatnya kerawanan sosial (kriminalitas dan krisis sosial), menurunnya produktivitas masyarakat akibat stress karena terbatasnya ruang publik yang tersedia untuk interaksi sosial, dan menimbulkan masalah kemacetan akibat tingginya hambatan samping di ruas ruas jalan tertentu.
\end{abstract}

Kata Kunci: penataan, upaya dan implikasi, RTH

\section{PENDAHULUAN}

Terbitnya Undang-undang Nomor 26 tahun 2007 tentang Penataan Ruang seiring dengan makin menguatnya keprihatinan global terhadap isu pemanasan global dan pembangunan berkelanjutan yang harus menjadi salah satu concern utama dalam pembangunan baik di negara maju maupun negara berkembang. Undang-undang tersebut mencantumkan bahwa setiap kota dalam rencana tata ruang wilayahnya diwajibkan untuk mengalokasikan sedikitnya $30 \%$ dari ruang atau wilayahnya untuk $\mathrm{RTH}$, dimana 20\% diperuntukan bagi RTH publik yang merupakan ruang terbuka hijau yang dimiliki dan dikelola oleh pemerintah kota dan digunakan untuk kepentingan masyarakat secara umum, serta $10 \%$ diperuntukan bagi RTH private pada lahan-lahan yang dimiliki oleh swasta atau masyarakat. Sedangkan keberadaan ruang publik di
Kota Pekanbaru, baru mencapai sekitar 8,5\% . Padahal menurut Perda Nomor 26 Tahun 2008, disebutkan pemerintahan kota, wajib menyediakan ruang publik sebesar 20 persen dari seluruh luas areal kota.

Ruang terbuka (open spaces) merupakan ruang yang direncanakan karena kebutuhan akan tempat-tempat pertemuan dan aktivitas bersama di udara terbuka. Ruang terbuka (open spaces), Ruang Terbuka Hijau (RTH), Ruang publik (public spaces) mempunyai pengertian yang hampir sama. Secara teoritis yang dimaksud dengan ruang terbuka (open spaces) adalah: Ruang yang berfungsi sebagai wadah (container) untuk kehidupan manusia, baik secara individu maupun berkelompok, serta wadah makhluk lainnya untuk hidup dan berkembang secara berkelanjutan.

Suatu wadah yang menampung aktivitas manusia dalam suatu lingkungan yang tidak 
mempunyai penutup dalam bentuk fisik. Ruang yang berfungsi antara lain sebagai tempat bermain aktif untuk anak-anak dan dewasa, tempat bersantai pasif untuk orang dewasa, dan sebagai areal konservasi lingkungan hijau. Ruang yang berdasarkan fungsinya sebagai ruang terbuka hijau yaitu dalam bentuk taman, lapangan atletik dan taman bermain.

Lahan yang belum dibangun atau sebagian besar belum dibangun di wilayah perkotaan yang mempunyai nilai untuk keperluan taman dan rekreasi; konservasi lahan dan sumber daya alam lainnya; atau keperluan sejarah dan keindahan. Ruang-ruang di dalam kota atau wilayah yang lebih luas baik dalam bentuk area/kawasan maupun dalam bentuk area memanjang/jalur yang dalam penggunaannya lebih bersifat terbuka yang pada dasarnya tanpa bangunan yang berfungsi sebagai kawasan pertamanan kota, hutan kota, rekreasi kota, kegiatan Olah Raga, pemakaman, pertanian, jalur hijau dan kawasan hijau pekarangan. Fasilitas yang memberikan kontribusi penting dalam meningkatkan kualitas lingkungan permukiman, dan merupakan suatu unsur yang sangat penting dalam kegiatan rekreasi.

Pengertian ruang publik (public spaces) adalah suatu ruang dimana seluruh masyarakat mempunyai akses untuk menggunakannya. Ciriciri utama daripublic spaces adalah: terbuka mudah dicapai oleh masyarakat untuk melakukan kegiatan-kegiatan kelompok dan tidak selalu harus ada unsur hijau, bentuknya berupa malls, plazas dan taman bermain. Jadi RTH lebih menonjolkan unsur hijau (vegetasi)dalam setiap bentuknya sedangkan public spaces dan ruang terbuka hanya berupa lahan terbuka belum dibangun yang tanpa tanaman. Public spaces adalah ruang yang dapat dinikmati oleh seluruh masyarakat sedangkan RTH dan ruang terbuka tidak selalu dapat digunakan dan dinikmati oleh seluruh masyarakat.

Menata hutan kota lebih hijau dan menambah ruang terbuka hijau (RTH) lebih banyak menjadi dambaan masyarakat Pekanbaru. Jika tidak, tentu polusi udara di Kota Pekanbaru makin tinggi akibat pertumbuhan kendaraan bermotor dan bangunan perumahan yang menggila di Kota
Bertuah. Ruang terbuka hijau kota merupakan bagian penting dari struktur pembentuk kota, dimana ruang terbuka hijau kota memiliki fungsi utama sebagai penunjang ekologis kota yang juga diperuntukkan sebagai ruang terbuka penambah dan pendukung nilai kualitas lingkungan dan budaya suatu kawasan. Keberadaan ruang terbuka hijau kota sangatlah diperlukan dalam mengendalikan dan memelihara integritas dan kualitas lingkungan. Ruang terbuka hijau memiliki dua fungsi utama, yaitu fungsi intrinsik sebagai penunjang ekologis dan fungsi ekstrinsik yaitu fungsi arsitektural (estetika), fungsi sosial dan ekonomi. Ruang terbuka hijau dengan fungsi ekologisnya bertujuan untuk menunjang keberlangsungan fisik suatu kota dimana ruang terbuka hijau tersebut merupakan suatu bentuk ruang terbuka hijau yang berlokasi, berukuran dan memiliki bentuk yang pasti di dalam suatu wilayah kota.

Sejumlah masyarakat di Kota Pekanbaru menaruh harapan besar kepada Wali Kota Pekanbaru agar memprioritaskan penghijauan Kota Pekanbaru dengan pohon pelindung pilihan. Sebab semakin lama pembangunan fisik di Kota Pekanbaru semakin pesat dengan gedunggedung pencakar langit. Sementara pembangunan penghijauan kota dengan pohon pelindung sangat minim. Sehingga bila berjalan di trotoar di pusat Kota Pekanbaru siapa saja merasa gerah, panas dan tak nyaman.

Minimnya fasilitas Ruang Terbuka Hijau (RTH), atau yang sering disebut ruang publik di Pekanbaru. Sehingga memunculkan problematika, terutama terhadap penggunaan area tertentu sebagai pengganti ruang publik. Misalnya banyak ditemui di pinggir jalan, taman kota atau bundaran air mancur, yang dijadikan tempat bersantai oleh warga. Sehingga mengundang para pedagang kaki lima, untuk berjualan di area tersebut, dan terjadi kemacetan jalan. Issue yang berkaitan dengan ruang terbuka publik atau ruang terbuka hijau secara umum terkait dengan beberapa tantangan tipikal perkotaan, seperti menurunnya kualitas lingkungan hidup di kawasan kota dan di lingkungan permukiman warga, bencana banjir/longsor dan perubahan perilaku sosial masyarakat yang cenderung kontra- 
produktif dan destruktif seperti kriminalitas dan vandalisme.

Dari aspek kondisi lingkungan hidup, rendahnya kualitas air tanah, tingginya polusi udara dan kebisingan di perkotaan, merupakan hal-hal yang secara langsung maupun tidak langsung terkait dengan keberadaan RTH secara ekologis. Di samping itu tingginya frekuensi bencana banjir dan tanah longsor di perkotaan dewasa ini juga diakibatkan karena terganggunya sistem tata air karena terbatasnya daerah resapan air dan tingginya volume air permukaan (runoff). Kondisi tersebut secara ekonomis juga dapat menurunkan tingkat produktivitas, dan menurunkan tingkat kesehatan dan tingkat harapan hidup masyarakat.

Secara sosial, tingginya tingkat kriminalitas dan konflik horizontal di antara kelompok masyarakat perkotaan secara tidak langsung juga dapat disebabkan oleh kurangnya ruang-ruang kota yang dapat menyalurkan kebutuhan interaksi sosial untuk pelepas ketegangan yang dialami oleh masyarakat perkotaan. Rendahnya kualitas lingkungan perumahan dan penyediaan ruang terbuka publik, secara psikologis telah menyebabkan kondisi mental dan kualitas sosial masyarakat yang makin buruk dan tertekan.

Sementara itu secara teknis, issue yang berkaitan dengan penyelenggaraan RTH di perkotaan antara lain menyangkut terjadinya suboptimalisasi penyediaan RTH baik secara kuantitatif maupun kualitatif, lemahnya kelembagaan dan SDM, kurangnya keterlibatan stakeholder dalam penyelenggaraan $\mathrm{RTH}$, serta terbatasnya ruang/lahan di kawasan permukiman yang dapat digunakan sebagai RTH.

Sub-optimalisasi ketersediaan RTH terkait dengan kenyataan masih kurang memadainya proporsi wilayah yang dialokasikan untuk ruang terbuka, maupun rendahnya rasio jumlah ruang terbuka per kapita yang tersedia. Sedangkan secara kelembagaan, masalah RTH juga terkait dengan belum adanya aturan perundangan yang memadai tentang RTH, serta pedoman teknis dalam penyelenggaraan RTH sehingga keberadaan RTH masih bersifat marjinal. Di samping itu, kualitas SDM yang tersedia juga harus ditingkatkan untuk dapat memelihara dan mengelola RTH secara lebih professional.

\section{METODE}

Pendekatan dalam penelitian ini dilakukan dengan metode kualitatif berdasarkan studi literatur yang dilakukan secara mendalam guna mempertajam analisis yang dipaparkan. Metode studi literatur digunakan untuk membantu penulis dalam memberikan analisis atas masalah yang menjadi sorotan. Data primer diperoleh dari hasil wawancara dan observasi lapangan. Sementara pemanfaatan sumber pustaka sebagai data sekunder untuk memperoleh data penelitian berupa buku, e-book, journal, e-journal, dan beragam laporan yang berkaitan dengan Ruang Terbuka Hijau (RTH) di Kota Pekanbaru. Data sekunder tersebut direduksi dan di sintesis sesuai dengan kebutuhan pembahasan.

\section{HASIL DAN PEMBAHASAN Bentuk dan Fungsi Ruang Terbuka Hijau (RTH)}

Ruang Terbuka Hijau (RTH) perkotaan adalah bagian dari ruang-ruang terbuka (open spaces) suatu wilayah perkotaan yang diisi oleh tumbuhan, tanaman dan vegetasi (endemik maupun introduksi) guna mendukung manfaat ekologis, sosial-budaya dan arsitektural yang dapat memberikan manfaat ekonomi (kesejahteraan) bagi masyarakatnya. Ruang terbuka non-hijau dapat berupa ruang terbuka yang diperkeras (paved) maupun ruang terbuka biru (RTB) yang berupa permukaan sungai, danau, maupun arealareal yang diperuntukkan sebagai genangan retensi.

Secara fisik RTH dapat dibedakan menjadi RTH alami yang berupa habitat liar alami, kawasan lindung dan taman-taman nasional, maupun RTH non-alami atau binaan yang seperti taman, lapangan olah raga, dan kebun bunga. Dari segi fungsi RTH dapat berfungsi secara ekologis, sosial/budaya, arsitektural, dan ekonomi. Secara ekologis RTH dapat meningkatkan kualitas air tanah, mencegah banjir, mengurangi polusi udara, dan menurunkan temperatur kota. Bentuk-bentuk RTH perkotaan yang berfungsi ekologis antara lain seperti sabuk hijau kota, hutan kota, taman botani, sempadan sungai dll. Secara sosial-budaya keberadaan RTH dapat memberikan fungsi sebagai ruang interaksi sosial, 
sarana rekreasi, dan sebagai tetenger kota yang berbudaya. Bentuk RTH yang berfungsi sosialbudaya antara lain taman-taman kota, lapangan olah raga, kebun raya, TPU dsb.

Secara arsitektural RTH dapat meningkatkan nilai keindahan dan kenyamanan kota melalui keberadaan taman-taman kota, kebun-kebun bunga, dan jalur-jalur hijau di jalan-jalan kota. Sementara itu RTH juga dapat memiliki fungsi ekonomi, baik secara langsung seperti pengusahaan lahan-lahan kosong menjadi lahan pertanian/ perkebunan (urban agriculture) dan pengembangan sarana wisata hijau perkotaan yang dapat mendatangkan wisatawan. Sementara itu secara struktur, bentuk dan susunan RTH dapat merupakan konfigurasi ekologis dan konfigurasi planologis. RTH dengan konfigurasi ekologis merupakan RTH yang berbasis bentang alam seperti, kawasan lindung, perbukitan, sempadan sungai, sempadan danau, pesisir dsb. Sedangkan RTH dengan konfigurasi planologis dapat berupa ruang-ruang yang dibentuk mengikuti pola struktur kota seperti RTH perumahan, RTH kelurahan, RTH kecamatan, RTH kota maupun taman-taman regional/ nasional. Dari segi kepemilikan RTH dapat berupa RTH public yang dimiliki oleh umum dan terbuka bagi masyarakat luas, atau RTH privat (pribadi) yang berupa taman-taman yang berada pada lahan-lahan pribadi.

Lawson (2001) mengungkapkan bahwa sebuah ruang memiliki dua fungsi yang signifikan, ruang dapat menyatukan sekelompok orang dan juga secara simultan ruang juga dapat memisahkan sekelompok orang satu sama lainnya. Ruang merupakan hal yang sangat esensial juga fundamental dan universal dari bentuk komunikasi. Ruang yang mengelilingi kita dan objek-objek yang berada di dalamnya dapat menentukan seberapa jauh kita dapat bergerak, seberapa hangat atau dingin kita merasa, seberapa banyak yang dapat kita lihat dan dengar, dan dengan siapa kita dapat berinteraksi. Dimana ruang terbuka didefinisikan sebagai bagian peruntukkan penggunaan tanah dalam wilayah kota yang disediakan untuk difungsikan sebagai daerah ruang terbuka yang dapat berupa lahan terbuka hijau, lapangan, pemakaman, tegalan, persawahan dan bentuk-bentuk lainnya.

De Chiara (1982) membagi ruang kota dalam beberapa klasifikasi yaitu ruang terbuka utilitas yang didasarkan pada fungsi ruang terbuka sebagai lahan yang memiliki kapasitas produksi dan berproduksi serta sebagai lahan cadangan, ruang terbuka hijau yang didasarkan pada ruang terbuka yang bersifat alamiah/natural yang dapat digunakan untuk rekreasi publik serta sebagai penyeimbang bangunan yang bersifat tidak permanen, ruang terbuka koridor yang merupakan ruang untuk pergerakan yang membentuk suatu sistem sirkulasi, serta ruang dengan klasifikasi dengan penggunaan yang beragam dimana dalam kategori ini ruang terbuka yang ada memiliki fungsi ganda, sebagai contoh hutan tadah hujan yang juga berfungsi sebagai ruang rekreasi.

Secara definitif, ruang terbuka hijau adalah kawasan atau areal permukaan tanah yang didominasi oleh tumbuhan yang dibina untuk fungsi perlindungan habitat tertentu, dan atau sarana lingkungan/kota, dan atau pengamanan jaringan

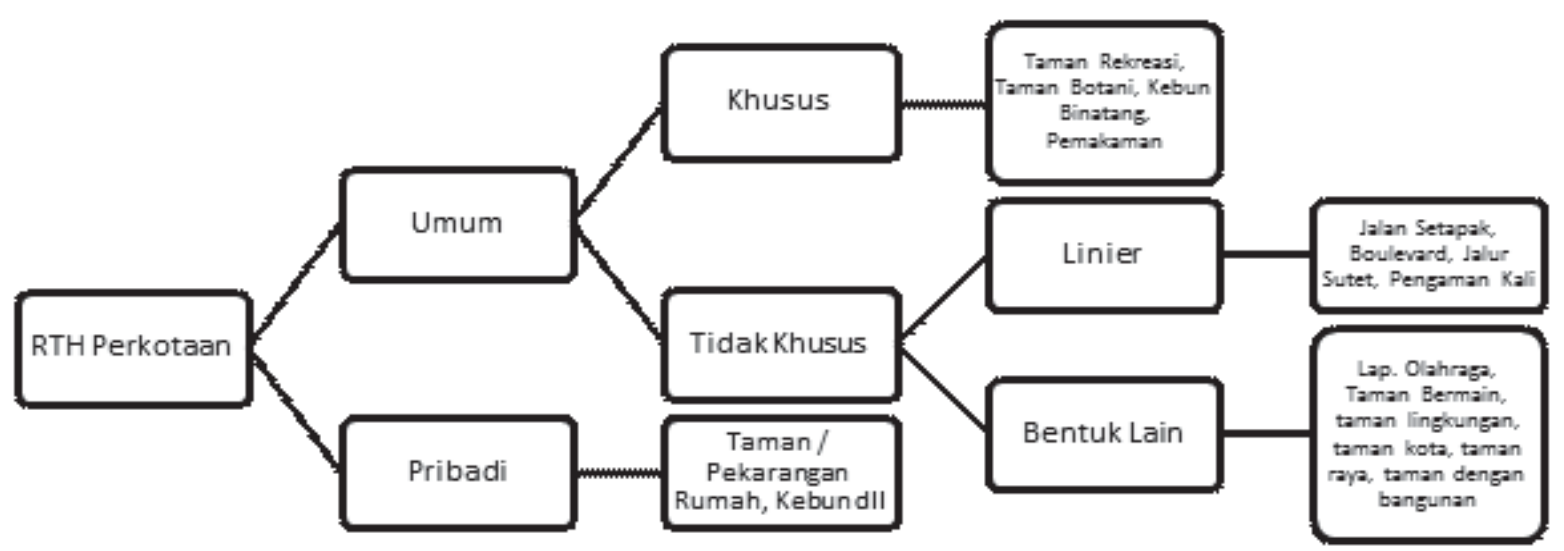

Gambar 1. Konsep Ruang Terbuka Hijau 
prasarana, dan atau budidaya pertanian. Selain untuk meningkatkan kualitas atmosfer, menunjang kelestarian air dan tanah, ruang terbuka hijau di tengah-tengah ekosistem perkotaan juga berfungsi untuk meningkatkan kualitas lansekap kota (Hakim, 2004). Berdasarkan Konferensi Tingkat Tinggi (KTT) Bumi di Rio de Janeiro, Brazil (1992) dan dipertegas lagi pada KTT Johannesburg, Afrika Selatan 10 tahun kemudian $(2002$, Rio +10$)$, telah disepakati bersama bahwa sebuah kota idealnya memiliki luas RTH minimal 30 persen dari total luas kota. Penyediaan ruang terbuka hijau pada wilayah perkotaan menurut Pedoman penyediaan dan pemanfaatan RTH di Kawasan Perkotaan terbagi menjadi ruang terbuka hijau publik dan ruang terbuka hijau privat dimana proporsi ruang terbuka hijau yang sesuai adalah sebesar $30 \%$ dari keseluruhan luas lahan yang komposisinya terbagi atas $20 \%$ ruang terbuka hijau publik dan $10 \%$ ruang terbuka hijau privat.

Ruang terbuka hijau pada suatu kota harus memenuhi luasan minimal ruang terbuka hijau sehingga dapat memenuhi fungsi dan memberikan manfaatnya dalam suatu kawasan kota dimana penyelenggaraan ruang terbuka hijau kota. Menurut Purnomohadi (2006) bertujuan untuk menjaga kelestarian, keserasian dan keseimbangan ekosistem perkotaan yang meliputi unsur-unsur lingkungan, sosial dan budaya, sehingga diharapkan dengan adanya Ruang Terbuka Hijau di kawasan perkotaan dapat berfungsi untuk mencapai identitas kota, upaya pelestarian plasma nutfah, penahan dan penyaring partikel padat dari udara, mengatasi genangan air, ameliorasi iklim, pelestarian air tanah, penapis cahaya silau, meningkatkan keindahan, sebagai habitat burung serta mengurangi masalah stress (tekanan mental) pada masyarakat kawasan perkotaan.

Dalam kaitannya dengan lansekap kota, ruang terbuka hijau kota merupakan suatu bagian penting dari keseluruhan lansekap kota, dimana ruang terbuka hijau berfungsi sebagai penunjang kualitas ekologis lansekap kota. Jika dalam suatu wilayah perkotaan proporsi dan distribusi ruang terbuka hijau kota sesuai dengan kebutuhan kota terutama kebutuhan masyarakat, maka kualitas ekologis lansekap kota akan terpenuhi dan kualitas hidup masyarakat kota akan semakin meningkat.

Molnar (1986) menyatakan bahwa untuk memenuhi kebutuhan ruang terbuka hijau bagi masyarakat perkotaan ada beberapa aspek utama yang harus dipertimbangkan yaitu hubungan antar ruang terbuka hijau dengan lingkungan sekitar, ruang terbuka hijau harus ditujukan untuk kepentingan masyarakat yang tetap memperhatikan aspek estetika dan fungsional, mengembangakan pengalaman substansial dari ruang terbuka hijau (efek dari garis, bentuk, tekstur dan warna), disesuaikan dengan karakter lahan dan karakter pengguna, memenuhi semua kebutuhan teknis dan pengawasan yang mudah. Melalui penjabaran referensi tentang ruang terbuka hijau tersebut untuk dapat mewujudkan ruang terbuka hijau didalam suatu wilayah perkotaan yang mampu berfungsi secara ekologis, estetis dan memiliki nilai sosial budaya dan ekonomi maka dibutuhkan adanya proporsi dan distribusi ruang terbuka hijau yang ideal terhadap suatu wilayah perkotaan, akan tetapi tetap memperhatikan kebutuhan masyarakat sebagai pengguna serta kebutuhan kota tersebut.

\section{Upaya Peningkatan Kualitas dan Kuantitas Ruang Terbuka Hijau (RTH)}

Upaya yang bisa dilakukan warga Kota Pekanbaru di halaman rumah masing-masing ialah dengan penanaman pohon atau tanaman, selain udara menjadi lebih sejuk, polusi udara juga bisa dikurangi. Untuk menutupi kekurangan tempat menyimpan cadangan air tanah, setiap keluarga bisa melengkapi rumahnya, yang masih memiliki sedikit halaman, dengan sumur resapan. Dengan sumur resapan itu, air hujan yang turun tidak terbuang percuma, tetapi ditampung di tanah.

Sumur resapan merupakan sistem resapan buatan yang dapat menampung air hujan, baik dari permukaan tanah maupun dari air hujan yang disalurkan melalui atap bangunan. Bentuknya dapat berupa sumur, kolam dengan resapan, dan sejenisnya. Pembuatan sumur resapan ini sekaligus akan mengurangi debit banjir dan genangan air di musim hujan. Salah satu contoh upaya yang baik untuk mengembalikan kualitas dan kuantitias RTH yang dapat diterapkan di 
lingkungan permukiman adalah beberapa kebijaksanaan perencanaan oleh pemerintah Kota Pekanbaru dalam menjaga keseimbangan ekologi lingkungan sebagai berikut:

1. Pada kawasan terbangun kota, harus disediakan RTH yang cukup yaitu:

a) Untuk kawasan yang padat, minimum disediakan area $10 \%$ dari luas total kawasan.

b) Untuk kawasan yang kepadatan bangunannya sedang harus disediakan ruang terbuka hijau minimum $15 \%$ dari luas kawasan.

c) Untuk kawasan berkepadatan bangunan rendah harus disediakan ruang terbuka hijau minimum $20 \%$ terhadap luas kawasan secara keseluruhan.

2. Pada kawasan terbangun kota, harus dikendalikan besaran angka Koefisien Dasar Bangunan (KDB) maupun Koefisien Lantai Bangunan (KLB) sesuai dengan sifat dan jenis penggunaan tanahnya. Secara umum pengendalian KDB dan KLB ini adalah mengikuti kaidah semakin besar kapling bangunan, nilai KDB dan KLB makin kecil, sedangkan semakin kecil ukuran kapling, maka nilai KDB dan KLB akan semakin besar.

3. Untuk mengendalikan kualitas air dan penyediaan air tanah, maka bagi setiap bangunan baik yang telah ataupun akan membangun disyaratkan untuk membuat sumur resapan air. Hal ini sangat penting artinya untuk menjaga agar kawasan terbangun kota, tinggi muka air tanah agar tidak makin menurun. Pada tingkat yang tinggi, kekurangan airpermukaan ini akan mampu mempengaruhi kekuatan konstruksi bangunan.

4. Untuk meningkatkan daya resap air ke dalam tanah, maka perlu dikembangkan kawasan resapan air yang menampung buangan air hujan dari saluran drainase. Upaya lain yang perlu dilakukan adalah dengan membuat kolam resapan air pada setiap wilayah tangkapan air.

5. Untuk kawasan pemukiman sebaiknya jarak maksimum yang ditempuh menuju salah satu jalur angkutan umum adalah 250 meter.
Beberapa upaya yang harus dilakukan oleh Pemerintah antara lain adalah:

1. Menetapkan kebutuhan luas minimum RTH sesuai dengan karakteristik kota, dan indikator keberhasilan pengembangan RTH suatu kota;

2. Meningkatkan kampanye dan sosialisasi tentangnya pentingnya RTH melalui gerakan kota hijau (green cities);

3. Mengembangkan mekanisme insentif dan disinsentif yang dapat lebih meningkatkan peran swasta dan masyarakat melalui bentukbentuk kerjasama yang saling menguntungkan;

4. Mengembangkan proyek-proyek percontohan RTH untuk berbagai jenis dan bentuk yang ada di beberapa wilayah Kota Pekanbaru.

\section{Implikasi Penyediaan Ruang Terbuka Hijau (RTH)}

Luas ruang terbuka hijau di Kota Pekanbaru adalah sekitar 31.750,341 hektar. Sebaran luas untuk masing-masing kecamatan adalah; Kecamatan Pekanbaru Kota 0,353 hektar, Senapelan 3,173 hektar, Limapuluh 50,246 hektar, Sukajadi 1,852 hektar, Sail 28,649 hektar, Rumbai 9.596,980 hektar, Bukit Raya 18.929,067 hektar, dan Tampan 3.140,021 hektar.

Kebutuhan ruang terbuka hijau berdasarkan existing condition ruang terbuka hijau. Kawasan terbuka hijau di Kota Pekanbaru sesuai dengan luas kawasan hijau yang ditetapkan 40 persen dari luas wilayah masih mencukupi. Berdasarkan hasil analisis penutupan lahan, perkiraan luas ruang terbuka hijau di Kota Pekanbaru mencapai 31.750,34 hektar atau sekitar 49,70 persen dari total luas Kota Pekanbaru (63.226 hektar). Untuk tingkat kecamatan ada 6 kecamatan yang tidak memenuhi syarat untuk mencukupi kebutuhan ruang terbuka hijau berdasarkan luas wilayah. Kekurangan ruang terbuka hijau pada kecamatan tersebut adalah Kecamatan Pekanbaru Kota dengan luas 89,65 hektar, Senapelan 262,83 hektar, Limapuluh 111,75 hektar, Sukajadi 202,15 hektar, Sail 101,35 hektar, dan Tampan 1.213,98 hektar. 
Kecamatan Rumbai dan Bukit Raya luas ruang terbuka hijau masih memenuhi syarat berdasarkan luas wilayah.

Berdasarkan kebutuhan penduduk dengan standar $40 \mathrm{~m} 2 /$ jiwa terdapat 5 kecamatan yang tidak memenuhi syarat kawasan terbuka hijau. Kekurangan ruang terbuka hijau terjadi pada Kecamatan Pekanbaru Kota dengan luas 121,92 hektar, Senapelan 142,77 hektar, Limapuluh 114,37 hektar, Sukajadi 244,49 hektar, dan Sail 57,61 hektar. Kecamatan Rumbai, Bukit Raya, dan Tampan luas ruang terbuka hijau yang ada masih memenuhi syarat untuk kebutuhan berdasarkan jumlah penduduk.

Berdasarkan jumlah karbon dioksida, Kecamatan Pekanbaru Kota tidak memenuhi syarat kawasan terbuka hijau. Kekurangan ruang terbuka hijau untuk menyerap karbon dioksida dengan luas 3.032,65 hektar. 7 kecamatan lainnya masih memenuhi syarat berdasarkan kebutuhan untuk menyerap karbon dioksida. Kebutuhan ruang terbuka hijau yang sangat besar di Kecamatan Kota Pekanbaru dikarenakan jumlah karbon dioksida yang besar serta keberadaan ruang terbuka hijau yang sangat sedikit.

Kebutuhan ruang terbuka hijau berdasarkan Rencana Umum Tata Ruang Kota (RUTRK) kawasan hijau. Kawasan terbuka hijau di Kota Pekanbaru berjumlah 12.790,73 hektar. Kebutuhan ruang terbuka hijau berdasarkan luas wilayah berjumlah 25.290,4 hektar. Terdapat kekurangan ruang terbuka hijau sekitar 12 . 499,67 hektar. Sesuai dengan luas kawasan hijau yang ditetapkan 40 persen dari luas wilayah belum mencukupi. Ruang terbuka hijau yang ditetapkan hanya berjumlah 16,83 persen. Seluruh Kecamatan di Kota Pekanbaru masih kekurangan ruang terbuka hijau berdasarkan luas wilayah. Kekurangannya masing-masing adalah Kecamatan Pekanbaru Kota dengan luas 90 hektar, Senapelan 266 hektar, Limapuluh 162 hektar, Sukajadi 204 hektar, Sail 130 hektar, Rumbai 5.305, 47 hektar, Bukit Raya 2.206,56 hektar, dan Tampan 4.135,24 hektar.

Kebutuhan ruang terbuka hijau berdasarkan jumlah penduduk terdapat 6 kecamatan yang belum memenuhi syarat. Kekurangan ruang terbuka hijau pada kecamatan tersebut adalah
Pekanbaru Kota 122,27 hektar, Senapelan 145,94 hektar, Limapuluh 164,62 hektar, Sukajadi 246,34 hektar, Sail 86,26 hektar, dan Tampan 390,95 hektar. Kecamatan Rumbai dan Bukit Raya masih mencukupi.

Kebutuhan ruang terbuka hijau untuk menyerap karbon dioksida terdapat 6 kecamatan yang tidak memenuhi syarat. Kekurangan luas ruang terbuka hijau pada kecamatan tersebut adalah Kecamatan Pekanbaru Kota 3.033,83 hektar, Senapelan 1 hektar, Limapuluh 1 hektar, Sukajadi 1 hektar, Sail 2 hektar, dan Tampan 179,24 hektar. Kecamatan Bukit Raya dan Tampan masih mencukupi. Arahan penambahan vegetasi dilakukan dengan pembangunan hutan kota dengan masing-masing adalah Kecamatan Pekanbaru Kota 3.033,19 hektar, Senapelan 266 hektar, Limapuluh 164,62 hektar, Sukajadi 246,34 hektar, Sail 130,40 hektar, Rumbai 5.305,67 hektar, Bukit Raya 2.206,76 dan Tampan 4.134,84 hektar.

\section{SIMPULAN}

Kecenderungan terjadinya penurunan kualitas ruang terbuka publik di kawasan permukiman, terutama ruang terbuka hijau (RTH) pada 30 tahun terakhir sangat signifikan. RTH yang ada sebagian besar telah dikonversi menjadi infrastruktur perkotaan seperti jaringan jalan, gedung-gedung perkantoran, pusat perbelanjaan, dan kawasan permukiman baru. Dalam upaya mewujudkan ruang yang nyaman, produktif dan berkelanjutan, maka sudah saatnya kita memberikan perhatian yang cukup terhadap keberadaan ruang terbuka public, khususnya RTH. Beberapa solusi yang dapat dilakukan antara lain membuat peraturan tentang standar penataan ruang berkaitan dengan penyediaan ruang terbuka hijau, serta upaya-upaya dalam skala kecil yang dapat dilakukan oleh masyarakat secara mandiri seperti menanam pohon atau tanaman, selain udara menjadi lebih sejuk, polusi udara juga bisa dikurangi. Untuk menutupi kekurangan tempat menyimpan cadangan air tanah, setiap keluarga bisa melengkapi rumahnya, yang masih memiliki sedikit halaman, dengan sumur resapan. 


\section{DAFTAR RUJUKAN}

Budihardjo, Eko. 2003, Kota Berwawasan Lingkungan. Bandung: Alumni

Groat, Linda \& Wang, David. 2002. Architectural Research Methods. Canada: John Wiley\& Sons,inc.

Purnomohadi, Ning. 2006. Ruang Terbuka Hijau Sebagai Unsur Utama Tata Ruang Kota. Jakarta: Direktorat Jenderal Penataan Ruang Kementrian Pekerjaan Umum.
Tim Departemen Arsitektur Lanskap Institut Pertanian Bogor. 2005. Makalah Lokakarya: Pengembangan Ruang Terbuka Hijau Di Kawasan Perkotaan. Direktorat Jenderal Penataan Ruang Departemen Pekerjaan Umum. Jakarta.

UU nomor 26 tahun 2007 tentang Penataan Ruang. Dept. Pekerjaan Umum. Jakarta, 2007. 